\title{
Health and Social Problems Associated with Recent Novel Psychoactive Substance (NPS) Use Amongst Marginalised, Nightlife and Online Users in Six European Countries
}

\author{
Marie Claire Van Hout ${ }^{1}$ (D) Annemieke Benschop ${ }^{2}$. \\ Michal Bujalski ${ }^{3}$ - Katarzyna Dąbrowska ${ }^{3}$. \\ Zsolt Demetrovics ${ }^{4}$ - Katalin Felvinczi ${ }^{4}$. \\ Evelyn Hearne $^{5}$ - Susana Henriques ${ }^{6}$ - Zsuzsa Kaló ${ }^{4}$. \\ Gerrit Kamphausen $^{7}$ • Dirk Korf ${ }^{2}$. Joana Paula Silva ${ }^{6}$. \\ Lukasz Wieczorek $^{3} \cdot$ Bernd Werse $^{7}$
}

(C) The Author(s) 2017. This article is an open access publication

\begin{abstract}
Continued diversification and use of new psychoactive substances (NPS) across Europe remains a public health challenge. The study describes health and social consequences of recent NPS use as reported in a survey of marginalised, nightlife and online NPS users in the Netherlands, Hungary, Portugal, Ireland, Germany and Poland $(n=3023)$. Some respondents were unable to categorise NPS they had used. Use of 'herbal blends' and 'synthetic
\end{abstract}

Marie Claire Van Hout m.c.vanhout@1jmu.ac.uk

Annemieke Benschop w.j.benschop@uva.nl

Michal Bujalski

bujalski@ipin.edu.pl

Katarzyna Dąbrowska dabrow@ipin.edu.pl

Zsolt Demetrovics demetrovics@t-online.hu

Katalin Felvinczi

katalin.felvinczi@gmail.com

Evelyn Hearne

evhearne1980@hotmail.com

Susana Henriques

susana_alexandra_henriques@ iscte-iul.pt

Zsuzsa Kaló

kalo.zsuzsa@ppk.elte.hu 
cannabinoids obtained pure' was most reported in Germany, Poland and Hungary, and use of 'branded stimulants' and 'stimulants/empathogens/nootropics obtained pure' was most reported in the Netherlands. Increased heart rate and palpitation, dizziness, anxiety, horror trips and headaches were most commonly reported acute side effects. Marginalised users reported substantially more acute side effects, more mid- and long-term mental and physical problems, and more social problems. Development of country-specific NPS awareness raising initiatives, health and social service needs assessments, and targeted responses are warranted.

Keywords Novel psychoactive substance $\cdot$ NPS · Marginalised drug user · Online drug user · Nightlife $\cdot$ Health and social consequences

The continued diffusion, diversification and use of new psychoactive substances (NPS) across Europe remains a public health, drug policy and legal challenge (Arfken et al. 2014; Reuter and Pardo 2017), with science, surveillance and law enforcement struggling to keep up with the increasing range of new designer NPS marketed to circumvent legislative controls (Hillebrand et al. 2010; Schmidt et al. 2010; Gunderson et al. 2012; Caudevilla et al. 2013; United Nations Office on Drugs and Crime, UNODC 2013; Seely et al. 2012; Spaderna et al. 2013; Corazza et al. 2013; Brents and Prather 2014; Papaseit et al. 2014; EMCDDA 2015; Caudevilla 2016; Van Hout and Hearne 2017; Kassai et al. 2017). The UNODC and the European Union (EU) define NPS as 'Substances of abuse, either in a pure form or a preparation, that are not controlled by the 1961 Single Convention on Narcotic Drugs or the 1971 Convention on Psychotropic Substances, but which may pose a public health threat' (UNODC 2013; Council of the European Union decision 2005/387/JHA 2005; Martinotti et al. 2015, 295; EMCDDA 2016). In general, NPS represent a multitude of synthetic and natural compounds marketed as legal alternative to conventional illicit

Gerrit Kamphausen

kamphausen@em.uni-frankfurt.de

Dirk Korf

d.j.korf@uva.nl

Joana Paula Silva

jpaulapbrsilva@gmail.com

Łukasz Wieczorek

lwieczorek@ipin.edu.pl

Bernd Werse

werse@em.uni-frankfurt.de

Public Health Institute, Liverpool John Moores University, Liverpool, UK

2 Bonger Institute, University of Amsterdam, Amsterdam, Netherlands

3 Institute of Psychiatry and Neurology, Warsaw, Poland

4 Institute of Psychology, Eötvös Loránd University, Budapest, Hungary

5 School of Health Sciences, Waterford Institute of Technology, Waterford, Ireland

6 Centre for Research and Studies in Sociology, University Institute of Lisbon, Lisbon, Portugal

7 Goethe-Universität, Frankfurt, Germany 
drugs, the most popular being cathinone derivatives, other amphetamine-type substances, and synthetic cannabinoids, observed since 2007 (Caudevilla 2016; EMCDDA 2016). By 2015, EMCDDA identified 101 NPS, in addition to the 450 NPS already monitored in their surveillance systems (EMCDDA 2015). Seven categories of NPS are adopted in the scientific literature, namely the stimulant/cathinone; GABA activating; hallucinogen, dissociative, cannabinoid, opioid and other/unspecified/uncategorised NPS (Van Hout and Hearne 2017). Sourcing remains an issue with ongoing availability online and offline interactions via friends and local contacts (Lavorgna 2014, 2016; Sande 2016; Soussan and Kjellgren 2016; van Amsterdam et al. 2015; Van Hout and Hearne 2017), despite legislative controls in street, nightlife and online markets (McElrath and O’Neill 2011; Wood et al. 2012; EMCDDA 2015; Caudevilla 2016; Van Hout and Hearne 2017; Reuter and Pardo 2017).

Eurobarometer surveys report that $8 \%$ of young Europeans have experience of use of NPS (Eurobarometer 2014). Typically, NPS users are young males (Werse and Morgenstern 2012), with several focuses regarding groups of users: These include more mature and experienced 'psychonauts' operating on the Surface Web and Dark Net (Soussan and Kjellgren 2014; Van Hout and Bingham 2013a, b; Van Hout and Hearne 2017). In some countries and/or regions, NPS use also occurs amongst early adopter drug scenes, for example gay and club dance scenes, and student populations (Psychonaut Web Mapping Research Group 2009; EuropolEMCDDA 2010; Dargan et al. 2010; Carhart-Harris et al. 2011; Measham et al. 2011a; Johnston et al. 2015) and street drug users who inject (Pas 2010; Colfax et al. 2010; Europol-EMCDDA 2010; Brauser 2012; Van Hout and Bingham 2012; Csák et al. 2013; Van Hout 2014a; Kapitány-Fövény et al. 2015; Hearne et al. 2016; Rácz et al. 2016). Motivations to use NPS are similar to conventional illicit drug use motives and include curiosity, drug and sexual pleasure, sensation seeking, self-exploration, street, peer and online availability, perceptions around value for money and legality, poor quality of available conventional illicit drugs, preferred desired and duration of effects, and habit or dependent use (Werse and Morgenstern 2012); Bourne et al. 2014; Soussan and Kjellgren 2016; Van Hout 2014b; van Amsterdam et al. 2015; Van Hout and Hearne 2015; Global Drug Survey (GDS) 2016; Schmidt et al. 2016). The engagement of NPS users and interested parties within online drug fora for information sharing and advice around harm reduction is also increasingly observed (Hearne and Van Hout 2016; Rosino and Linders 2015; Soussan and Kjellgren 2015, 2016; Van Hout 2014a, b; Van Buskirk et al. 2016; Van Hout and Hearne 2015, 2017).

Social and legal consequences generally include the effects of NPS use on individuals, families, communities and the society in general. Use of NPS is associated with a range of acute and chronic health harms which are dependent on user characteristics and vulnerabilities, environmental characteristics, level of dosage, toxicity, route of administration and the presence of other substances. Such harms generally centre on adverse cardiovascular, respiratory and gastro-intestinal consequences of use, transmission of blood borne viruses (HIV, Hepatitis C), neurological and psychiatric harms (for example psychosis and suicidal ideation), dependence and death (Every-Palmer 2010; Hadlock et al. 2011; Maan and D'Souza 2011; Lusthof et al. 2011; Werse and Morgenstern 2012; Kasick et al. 2012; Grandy 2012; Seely et al. 2012; Gunderson et al. 2012; King and Nutt 2014; Abdulrahim et al. 2015; Van Hout 2016).

We report here on the declared acute and chronic health consequences of NPS use, and incurred social and legal problems as reported by the three groups of identified European NPS users, namely, socially marginalised users who are high risk drug users often unemployed, homeless and/or in care; nightlife users who are recreational drug users frequenting clubs, raves and/or festivals often in education and/or employed; and users active on the Internet and 
carrying out their NPS activity in online communities known as drug fora. The aim of the study was to describe health, social and legal consequences of NPS use as reported by NPS users resident in these six European countries. The research questions centred on investigating if there are associations of certain problems with groups of NPS users; whether there are differences between countries within these groups; and what associations occur in current use of certain categories of NPS.

\section{Methods}

This study was undertaken within the remit of a transnational and interdisciplinary EU funded research project undertaken by researchers from different scientific disciplines in six EUcountries: Germany, Hungary, Ireland, the Netherlands, Poland and Portugal. A survey was designed based on extensive literature reviewing, country reports and expert consultations in each country, and which investigated user demographic characteristics, prevalence and patterns of use of illicit drugs; prevalence and patterns of NPS use; and reported health and social problems associated with use of NPS. Information was gathered on the use of seven categories of NPS: 'herbal blends (e.g. "Spice")'; 'synthetic cannabinoids (obtained pure)'; 'branded stimulants (e.g. "bath salts”)'; 'stimulants/empathogens/nootropics (obtained pure, e.g. mephedrone, MDPV, a-PVP)'; 'psychedelics (e.g. NBOMe-x, 2C-x'); 'dissociatives (e.g. methoxetamine)'; and 'other'. The questionnaire was developed in English and translated into the other languages in this project. To guarantee comparability, translation was done back and forth (from/into English).

Fieldwork occurred in the first 10 months of 2016. Eligibility criteria for the survey were (1) recent NPS use (at least once in the past 12 months), (2) resident of the participating countries and (3) 18 years or older. A targeted sampling methodology was chosen to reach NPS users in each of the three groups in the six participating countries:

1. Socially marginalised users were recruited face-to-face in the street, at or through user organisations and care facilities (e.g. low threshold facilities, consumption rooms) and through snowball sampling. Respondents were asked to either self-complete a pen-andpaper questionnaire, have a fieldworker read out the questions and record their answers, or complete an online questionnaire to which they were referred by a flyer containing a link and an individual code. In most cases, pen-and-paper questionnaires were intervieweradministered.

2. Users in night life were recruited face-to-face on-site at clubs, raves and festivals and through snowball sampling. Respondents were given the choice to self-complete either the pen-and-paper or online questionnaire.

3. Users in online communities were recruited by actively promoting the survey on internet fora and other online resources. Users in online communities were only given access to the online questionnaire.

The data was screened/cross-checked for errors and analysed using SPSS V.24. Analysis was conducted using anonymised data and involved descriptive statistics, including frequencies and percentages. Statistical tests included chi-square tests to assess differences in categorical data as well as ANOVA for mean comparison tests. Multivariate binary regression analyses were performed to determine which factors were associated with acute unpleasant 
side effects, mid- or long-term problems and social problems. In all statistical analyses, a twosided significance level of $5 \%$ was used.

Respondents were asked about their use of NPS as it related to the seven categories; 'herbal blends'; 'synthetic cannabinoids obtained pure'; 'branded stimulants'; 'stimulants/ empathogens/nootropics obtained pure'; 'psychedelics'; 'dissociatives' and 'other'. The survey responses revealed that some respondents were unable to categorise NPS they had used. This was especially evident in the categories of 'herbal blends' and 'synthetic cannabinoids obtained pure', and 'branded stimulants' and 'stimulants/empathogens/nootropics obtained pure'. Names of NPS were not always entered under their proper categories; respondents were unaware of active ingredients and names of NPS they had used. For this reason, for reporting purposes, these categories were combined.

\section{Results}

Three thousand five hundred three respondents were recruited, with 260 excluded as per eligibility criteria (residency/below 18 years). Of the remaining 3243 respondents, 212 were excluded because they either reported not using any NPS in the past 12 months (189/212), they answered or obviously answered the detailed questions on prevalence for non-NPS substances only, or answered negatively to the specific NPS categories. Eight further respondents were removed due to angry, incoherent or irrelevant responses in the open-ended text boxes.

\section{Respondent Profile}

The final data set for analysis was 3023 recent NPS users. See Table 1 . The online community sample was the largest (2110) and the marginalised sample was the smallest (266) across the six countries. Recruitment complexities such as low reporting of recent NPS use among certain categories of drug users in different countries was particularly evident in the marginalised respondents from the Netherlands and Portugal, and night life respondents from Ireland, with less than 10 respondents.

In terms of examining all three samples across the six countries, more than three thirds of respondents were male (marginalised $71.7 \%$, night life $67.9 \%$, online $68.0 \%$ ). See Table 2. The online community respondents were youngest with an average age of

Table 1 Sample countries

\begin{tabular}{|c|c|c|c|c|}
\hline & Marginalised & Night life & Online & Total \\
\hline \multicolumn{5}{|l|}{ Sample } \\
\hline Germany & 23 & 98 & 542 & 663 \\
\hline Hungary & 101 & 15 & 156 & 272 \\
\hline Ireland & 48 & 3 & 11 & 62 \\
\hline The Netherlands & 1 & 189 & 1000 & 1190 \\
\hline Poland & 86 & 172 & 338 & 596 \\
\hline Portugal & 7 & 170 & 63 & 240 \\
\hline Total & 266 & 647 & 2110 & 3023 \\
\hline
\end{tabular}


Table 2 Respondent profile

\begin{tabular}{|c|c|c|c|c|}
\hline & $\begin{array}{l}\text { Marginalised } \\
n=266\end{array}$ & $\begin{array}{l}\text { Night life } \\
n=647\end{array}$ & $\begin{array}{l}\text { Online } \\
n=2.110\end{array}$ & $p$ \\
\hline \multicolumn{5}{|l|}{ Gender } \\
\hline Male & $71.7 \%$ & $67.9 \%$ & $68.0 \%$ & \multirow[t]{2}{*}{.457} \\
\hline Female & $28.3 \%$ & $21.1 \%$ & $32.0 \%$ & \\
\hline \multicolumn{5}{|l|}{ Age } \\
\hline $18-24$ years & $17.4 \%$ & $50.1 \%$ & $70.3 \%$ & \multirow[t]{4}{*}{.000} \\
\hline $25-34$ years & $36.7 \%$ & $41.7 \%$ & $23.7 \%$ & \\
\hline $35-44$ years & $35.9 \%$ & $7.6 \%$ & $5.1 \%$ & \\
\hline 45 years and older & $10.0 \%$ & $0.6 \%$ & $1.0 \%$ & \\
\hline Average (sd) & $33.5(8.7)$ & $25.7(5.9)$ & $23.6(5.8)$ & .000 \\
\hline \multicolumn{5}{|l|}{ Residence } \\
\hline Small town (pop. $<50.000)$ & $6.1 \%$ & $17.3 \%$ & $41.2 \%$ & \multirow[t]{3}{*}{.000} \\
\hline Medium town (pop. 50.000-100.000) & $8.1 \%$ & $14.0 \%$ & $17.0 \%$ & \\
\hline Large town (pop. > 100.000) & $85.8 \%$ & $68.6 \%$ & $41.8 \%$ & \\
\hline \multicolumn{5}{|l|}{ Living arrangements } \\
\hline Own home & $6.9 \%$ & $20.8 \%$ & $14.5 \%$ & \multirow[t]{7}{*}{.000} \\
\hline Rent apartment or room & $14.6 \%$ & $47.1 \%$ & $39.6 \%$ & \\
\hline Parents/family & $16.5 \%$ & $27.6 \%$ & $44.1 \%$ & \\
\hline Friend's home & $9.6 \%$ & $3.4 \%$ & $1.1 \%$ & \\
\hline Residential care & $7.7 \%$ & $0.6 \%$ & $0.2 \%$ & \\
\hline Homeless accommodation/hostel & $32.3 \%$ & $0.3 \%$ & $0.2 \%$ & \\
\hline Other & $12.3 \%$ & $0.2 \%$ & $0.4 \%$ & \\
\hline \multicolumn{5}{|l|}{ Level of education } \\
\hline None & $7.7 \%$ & $0.3 \%$ & $0.6 \%$ & \multirow[t]{5}{*}{.000} \\
\hline Primary school & $47.5 \%$ & $16.9 \%$ & $12.8 \%$ & \\
\hline Secondary school & $37.9 \%$ & $45.2 \%$ & $56.2 \%$ & \\
\hline College/university & $5.7 \%$ & $37.3 \%$ & $28.5 \%$ & \\
\hline Doctor's degree, $\mathrm{PhD}$, etc. & $1.1 \%$ & $0.3 \%$ & $1.9 \%$ & \\
\hline \multicolumn{5}{|l|}{ Employment } \\
\hline Student & $3.1 \%$ & $28.6 \%$ & $43.7 \%$ & \multirow[t]{6}{*}{.000} \\
\hline Full-time worker & $3.5 \%$ & $39.0 \%$ & $30.6 \%$ & \\
\hline Part-time or casual worker & $9.4 \%$ & $12.0 \%$ & $11.7 \%$ & \\
\hline Self-employed & $5.9 \%$ & $9.3 \%$ & $5.4 \%$ & \\
\hline Unemployed/benefits & $75.7 \%$ & $10.8 \%$ & $8.1 \%$ & \\
\hline Other & $2.4 \%$ & $0.3 \%$ & $0.5 \%$ & \\
\hline
\end{tabular}

23.6 years, with $70.3 \%$ falling within the $18-24$ age group. The night life respondents were on average 25.7 years. The marginalised respondents were oldest across all countries with an average of 33.5 years. In terms of location, the majority of marginalised and night life respondents were resident in large towns with more than 100.000 inhabitants $(86.8 / 68.5 \%$, respectively). Most of the night life and online community respondents lived either with their parents or family (27.6 and 44.1\%), or in a rented accommodation (47.1 and 39.6\%). A substantial proportion of the marginalised respondents in contrast reported living in homeless accommodations or hostels $(32.3 \%)$ or other living arrangements (12.3\%), including living on the streets (sleeping rough). Both night life and online respondents reported higher levels of education. Many had completed a secondary level education (46.2/56.2\%, respectively), were studying for a higher degree $(28.6 / 43.7 \%$, respectively), or reported having a college or university diploma $(37.3 / 28.6 \%$, respectively). The majority of the marginalised respondents had completed none or just primary education $(55.2 \%)$, with a minority being students $(3.1 \%)$. The majority also were unemployed and/or living on benefits $(75.7 \%)$. 


\section{Use of NPS}

In terms of categories of NPS used, when comparing the six countries, use of 'herbal blends' and 'synthetic cannabinoids obtained pure' was most reported in Germany, Poland and Hungary, and use of 'branded stimulants' and 'stimulants/empathogens/nootropics obtained pure' was most reported in the Netherlands. See Table 3. Recent use of 'psychedelics' was most commonly reported by respondents from Portugal and Germany. To some degree, these results reflect the different sizes of subsamples in different countries, e.g. with Portuguese respondents mainly coming from nightlife settings, or Hungarian respondents who often were marginalised users.

When looking at frequent use of particular NPS categories, marginalised users were much more likely to show such patterns than the other two groups: $17.9 \%$ of the marginalised respondents reported daily herbal blend/synthetic cannabinoid use, compared to $1.2 \%$ of the night life and $2.8 \%$ of the online respondents. The respective figures for daily stimulant NPS use are $18.2 \%$ (marginalised), $0.3 \%$ (night life) and $1.0 \%$ (online). In terms of route of administration, the majority of marginalised respondents reported life time intravenous use (74.4\%), compared to $3.6 \%$ of night life and $4.9 \%$ of online respondents. These observations were also reflected in the modes of NPS administration: while $51.1 \%$ of the marginalised users mentioned injection as the preferred mode of administration, only $0.8 \%$ of the other groups did so. Overall, swallowing was the most prevalent mode (online 61.6, night life 45.6, marginalised $2.6 \%$ ).

\section{Side Effects of NPS Use and Associated Health and Social Problems}

Within all three subsamples, the majority of recent NPS users had experienced acute unpleasant side effects after NPS use. See Table 4. In terms of reporting of acute side effects, experiences of increased heart rate and palpitation, dizziness, anxiety and horror trips and headaches were reported as most common across all three categories. The proportion who had experienced these effects was substantially larger in the marginalised sample (85.3\%), than in the night life and online community samples (58.8 and 51.0\%). When looking at the separate side effects, there are significant differences between the three groups in every symptom, with

Table 3 Life time use of NPS categories

Herbal blends and/or pure synthetic cannabinoids
Branded and/or pure stimulants
Psychedelics Dissociatives Other NPS

\begin{tabular}{|c|c|c|c|c|c|c|c|c|c|c|}
\hline \multicolumn{11}{|l|}{ Sample } \\
\hline Marginalised & $73.3 \%$ & \multirow[t]{3}{*}{.000} & $85.0 \%$ & \multirow[t]{3}{*}{.000} & $22.2 \%$ & .000 & $22.6 \%$ & \multirow[t]{3}{*}{.896} & $10.9 \%$ & \multirow[t]{3}{*}{.000} \\
\hline Night life & $55.8 \%$ & & $73.1 \%$ & & $56.7 \%$ & & $21.6 \%$ & & $13.0 \%$ & \\
\hline Online community & $46.2 \%$ & & $79.9 \%$ & & $51.3 \%$ & & $21.3 \%$ & & $34.3 \%$ & \\
\hline \multicolumn{11}{|c|}{ Country } \\
\hline Germany & $63.0 \%$ & \multirow[t]{6}{*}{.000} & $50.1 \%$ & \multirow[t]{6}{*}{.000} & $75.9 \%$ & .000 & $33.9 \%$ & .000 & $37.6 \%$ & \multirow[t]{6}{*}{.000} \\
\hline Hungary & $89.7 \%$ & & $79.4 \%$ & & $26.1 \%$ & & $28.3 \%$ & & $32.7 \%$ & \\
\hline Ireland & $48.4 \%$ & & $88.7 \%$ & & $21.0 \%$ & & $11.3 \%$ & & $17.7 \%$ & \\
\hline The Netherlands & $16.6 \%$ & & $96.7 \%$ & & $40.0 \%$ & & $10.3 \%$ & & $21.8 \%$ & \\
\hline Poland & $81.5 \%$ & & $82.9 \%$ & & $40.3 \%$ & & $27.9 \%$ & & $30.4 \%$ & \\
\hline Portugal & $64.2 \%$ & & $57.1 \%$ & & $85.8 \%$ & & $21.7 \%$ & & $19.6 \%$ & \\
\hline
\end{tabular}


Table 4 Side effects and problems from NPS use among marginalised, night life and online NPS users

\begin{tabular}{|c|c|c|c|c|}
\hline & $\begin{array}{l}\text { Marginalised } \\
n=266\end{array}$ & $\begin{array}{l}\text { Night life } \\
n=647\end{array}$ & $\begin{array}{l}\text { Online } \\
n=2.110\end{array}$ & $p$ \\
\hline \multicolumn{5}{|l|}{ Acute unpleasant side effects } \\
\hline Increased heart rate/palpitation & $57.5 \%$ & $37.7 \%$ & $35.8 \%$ & .000 \\
\hline Headaches & $51.5 \%$ & $26.6 \%$ & $18.9 \%$ & .000 \\
\hline Stomach ache & $38.0 \%$ & $18.2 \%$ & $12.8 \%$ & .000 \\
\hline Dizziness & $44.7 \%$ & $29.2 \%$ & $20.7 \%$ & .000 \\
\hline Muscle cramps & $33.1 \%$ & $15.0 \%$ & $12.7 \%$ & .000 \\
\hline Loss of consciousness/coma & $23.3 \%$ & $9.9 \%$ & $6.7 \%$ & .000 \\
\hline Anxiety/horror trips & $47.7 \%$ & $25.5 \%$ & $21.2 \%$ & .000 \\
\hline Shortness of breath & $36.8 \%$ & $16.0 \%$ & $13.1 \%$ & .000 \\
\hline Hyperthermia & $33.5 \%$ & $17.8 \%$ & $17.7 \%$ & .000 \\
\hline Aggression/violence & $35.7 \%$ & $11.1 \%$ & $4.9 \%$ & .000 \\
\hline Paranoia & $52.3 \%$ & $21.9 \%$ & $17.7 \%$ & .000 \\
\hline Other & $4.1 \%$ & $4.9 \%$ & $6.3 \%$ & .221 \\
\hline Total & $85.3 \%$ & $58.8 \%$ & $51.0 \%$ & .000 \\
\hline \multicolumn{5}{|l|}{ Mid- or long-term problems } \\
\hline Addiction/withdrawal/craving & $46.2 \%$ & $7.4 \%$ & $12.1 \%$ & .000 \\
\hline Depression & $43.2 \%$ & $13.6 \%$ & $14.5 \%$ & .000 \\
\hline Paranoid disorders & $38.7 \%$ & $9.6 \%$ & $8.2 \%$ & .000 \\
\hline Weight loss & $46.2 \%$ & $9.6 \%$ & $9.5 \%$ & .000 \\
\hline Harms of injecting & $26.7 \%$ & $0.5 \%$ & $0.8 \%$ & .000 \\
\hline Other mental problems & $15.8 \%$ & $6.3 \%$ & $8.6 \%$ & .000 \\
\hline Other physical problems & $12.4 \%$ & $4.2 \%$ & $6.4 \%$ & .000 \\
\hline Total & $70.3 \%$ & $28.4 \%$ & $30.9 \%$ & .000 \\
\hline \multicolumn{5}{|l|}{ Social problems } \\
\hline Conflict at school, university, etc. & $6.8 \%$ & $4.3 \%$ & $4.7 \%$ & .277 \\
\hline Conflict at work & $12.0 \%$ & $5.6 \%$ & $3.8 \%$ & .000 \\
\hline Conflicts with partner or family & $45.9 \%$ & $13.6 \%$ & $12.8 \%$ & .000 \\
\hline Problems regarding housing & $42.5 \%$ & $3.7 \%$ & $3.1 \%$ & .000 \\
\hline Legal problems & $35.7 \%$ & $6.2 \%$ & $5.5 \%$ & .000 \\
\hline Other & $3.0 \%$ & $1.1 \%$ & $1.7 \%$ & .117 \\
\hline Total & $69.1 \%$ & $22.1 \%$ & $22.2 \%$ & .000 \\
\hline
\end{tabular}

mostly much higher proportions of marginalised users reporting these effects. When comparing night life users and online community users, night life users reported more unpleasant effects, especially head and stomach aches and dizziness. However, in all categories, marginalised users show much higher rates than the two other groups. Increased heart rate or palpitation was the most reported side effect in all three samples.

Marginalised users when compared to the other two categories reported also more mid- and long-term mental and physical problems (addiction withdrawals and craving, weight loss, depression and paranoid disorders) $(70.3 \%$ ) than the night life and online community samples (28.4 and $30.9 \%$ ). In terms of mid- to long-term consequences of use, addiction withdrawals and craving were reported by almost half of marginalised users along with weight loss, depression and paranoid disorders. In comparison, such experiences were reported by a minority of online and nightlife users. Across all three categories, however, paranoid disorders, depression, weight loss and symptoms of addiction were most common. Marginalised users also reported more social problems as a consequence of NPS use than the other groups of users (mainly conflicts with partner or family, problems with housing and legal problems) (69.1 versus 22.1 and 22.2\%). Low proportions of online and nightlife users reported social or legal problems. If any, respondents from these groups were most likely to report conflicts with 
partner or family, while, in contrast to the marginalised users, problems regarding housing and legal problems were relevant for very few nightlife and online respondents. See Table 4.

The proportions of different problems experienced by the respondents vary substantially by country of residence. See Table 5. Irish, Hungarian and Polish respondents were generally much more likely to report problems than Dutch or Portuguese users, with German users ranking in between. When looking at different types of problems, mid- and long-term problems, including social problems, were most prevalent in Ireland and Hungary. However, to a substantial degree, these differences reflect the varying distribution of user groups in the national samples (see Table 1 and the later 'regression analysis'). When looking at side effects and problems among those who have experience in the use of different NPS categories, some differences were evident. See Table 5; no comparative statistical analysis given here because of overlapping groups. Overall, these results show a consistent picture that dissociatives and synthetic cannabinoids are the substances that are mostly associated to such problems. Interestingly, this is true for nearly all kinds of problems, no matter if physical, mental or social, and no matter if these are long-term (including addiction and withdrawal) or acute effects.

\section{Regression Analyses}

Results show that negative experiences from NPS use are related to both type of user, country and categories of NPS used. Multivariate binary regression analyses was conducted to determine which of these three factors was most strongly associated with acute unpleasant side effects, mid- or long-term problems, and social problems. For type of user, marginalised users were chosen as the reference category, as they clearly deviate from the other two subsamples. For country, Ireland was chosen as the reference category, because respondents from the Irish sample most often reported negative experiences. Life time use of NPS categories were entered as dummy variables $(1=$ yes, $0=$ no). See Table 6 . Results indicate that online community NPS users - but not night life users - have less often experienced acute unpleasant side effects from NPS use than marginalised users, that Irish NPS users have experienced more side effects than NPS users from other countries, and that life time use of

Table 5 Side effects and problems from NPS use per country and per lifetime use

\begin{tabular}{|c|c|c|c|c|c|c|}
\hline \multirow{2}{*}{ Country } & \multicolumn{2}{|c|}{$\begin{array}{l}\text { Acute unpleasant } \\
\text { side effects }\end{array}$} & \multicolumn{2}{|c|}{$\begin{array}{l}\text { Mid- or long-term } \\
\text { problems }\end{array}$} & \multicolumn{2}{|c|}{$\begin{array}{l}\text { Social } \\
\text { problems }\end{array}$} \\
\hline & & & & \multirow{5}{*}{.000} & & \\
\hline Germany & $62.2 \%$ & \multirow{6}{*}{.000} & $26.9 \%$ & & $22.9 \%$ & \multirow{6}{*}{.000} \\
\hline Hungary & $78.7 \%$ & & $63.7 \%$ & & $60.4 \%$ & \\
\hline Ireland & $95.2 \%$ & & $70.5 \%$ & & $74.6 \%$ & \\
\hline The Netherlands & $35.7 \%$ & & $24.7 \%$ & & $9.5 \%$ & \\
\hline Poland & $78.5 \%$ & & $49.3 \%$ & & $47.2 \%$ & \\
\hline Portugal & $42.2 \%$ & & $15.5 \%$ & & $15.2 \%$ & \\
\hline \multicolumn{7}{|l|}{ Life time use } \\
\hline Herbal blends and/or pure synthetic cannabinoids & $69.7 \%$ & & $42.6 \%$ & & $38.6 \%$ & \\
\hline Branded and/or pure stimulants & $56.4 \%$ & & $37.2 \%$ & & $28.8 \%$ & \\
\hline Psychedelics & $56.8 \%$ & & $30.9 \%$ & & $25.6 \%$ & \\
\hline Dissociatives & $72.1 \%$ & & $44.5 \%$ & & $39.8 \%$ & \\
\hline Other NPS & $61.0 \%$ & & $39.4 \%$ & & $34.4 \%$ & \\
\hline
\end{tabular}


Table 6 Regression analysis of side effects and problems from NPS use across groups and lifetime use of NPS

\begin{tabular}{|c|c|c|c|c|c|c|c|c|c|}
\hline & \multicolumn{3}{|c|}{$\begin{array}{l}\text { Acute unpleasant } \\
\text { side effects }\end{array}$} & \multicolumn{3}{|c|}{$\begin{array}{l}\text { Mid- or long-term } \\
\text { problems }\end{array}$} & \multicolumn{3}{|c|}{ Social problems } \\
\hline & $\mathrm{B}$ & S.E. & $\mathrm{p}$ & $\mathrm{B}$ & S.E. & $\mathrm{p}$ & $\mathrm{B}$ & S.E. & $\mathrm{p}$ \\
\hline \multicolumn{10}{|l|}{ Marginalised (reference category) } \\
\hline Night life & -.309 & .220 & .159 & -.951 & .187 & .000 & -1.076 & .192 & .000 \\
\hline Online community & -.683 & .207 & .001 & -.986 & .172 & .000 & -1.139 & .174 & .000 \\
\hline \multicolumn{10}{|l|}{ Ireland (reference category) } \\
\hline Germany & -2.115 & .619 & .001 & -1.118 & .329 & .001 & -1.632 & .349 & .000 \\
\hline Hungary & -1.702 & .622 & .006 & -.095 & .330 & .773 & -.510 & .348 & .142 \\
\hline The Netherlands & -3.048 & .616 & .000 & -1.190 & .323 & .000 & -2.485 & .348 & .000 \\
\hline Poland & -1.634 & .616 & .008 & -.485 & .319 & .129 & -.820 & .338 & .015 \\
\hline Portugal & -3.181 & .630 & .000 & -1.803 & .369 & .000 & -2.125 & .390 & .000 \\
\hline $\begin{array}{l}\text { Life time use of herbal blends and/or pure } \\
\text { synthetic cannabinoids }\end{array}$ & .556 & .099 & .000 & .430 & .106 & .000 & .596 & .121 & .000 \\
\hline $\begin{array}{l}\text { Life time use of branded and/or pure } \\
\text { stimulants }\end{array}$ & .460 & .115 & .000 & .728 & .126 & .000 & .799 & .135 & .000 \\
\hline Life time use of psychedelics & .094 & .095 & .325 & -.087 & .101 & .389 & .104 & .119 & .383 \\
\hline Life time use of dissociatives & .473 & .118 & .000 & .337 & .118 & .004 & .265 & .129 & .039 \\
\hline Life time use of other NPS & -.030 & .101 & .763 & .181 & .102 & .077 & .377 & .115 & .001 \\
\hline Constant & 2.453 & .607 & .000 & .222 & .316 & .484 & .275 & .336 & .414 \\
\hline Nagelkerke $\mathrm{R}^{2}$ & .236 & & & .184 & & & .309 & & \\
\hline
\end{tabular}

herbal blends and/or pure synthetic cannabinoids, branded and/or pure stimulants, and dissociative NPS - but not psychedelic or other NPS is associated with unpleasant side effects. These associations between group, country and category of NPS used are independent from each other. Differences between countries, for instance, exist regardless of group of NPS users or life time use of categories of NPS. To illustrate this: among Irish marginalised life time users of stimulant NPS, 97.8\% have ever experienced acute unpleasant side effects of NPS use, while among Hungarian marginalised life time users of stimulant NPS, this proportion was significantly smaller at $80.5 \%$ (chi-square $=7.553, p=.006$ ). Thus, while the large differences between countries mainly reflect the varying distribution of user groups, there are also significant differences in the same user group by country. As for mid- or long-term problems, these are associated with being a marginalised user, living in Ireland, Hungary or Poland, and life time use of herbal blends and/or pure synthetic cannabinoids, branded and/or pure stimulants, and dissociative NPS. Social problems are associated with being a marginalised user, living in Ireland or Hungary, and life time use of herbal blends and/or pure synthetic cannabinoids, branded and/or pure stimulants, dissociative NPS, and other NPS.

\section{Discussion}

This study was undertaken within the remit of a transnational and interdisciplinary EU funded research project undertaken by researchers from different scientific disciplines in six EUcountries: Germany, Hungary, Ireland, the Netherlands, Poland and Portugal. Limitations of the prevalence and other data centre on the varied composition of country samples. Key findings centre on the particular trends visible in NPS use across countries, and the three identified NPS user groups (marginalised, nightlife and online). Most notable and similar to other research (Measham et al. 2011a; Van Hout 2016) was that the concept of NPS was not 
always clear at consumer level, with some users not clear on what NPS category they had used, and were unaware of the active ingredients. Additional limitations centred on the general nature of questions of negative experiences when using NPS which could have biased associations when multiple NPS categories were used within poly drug using episodes. We also recognise that respondents may have been recollecting negative experiences and may have since ceased using that particular NPS.

Proportions of marginalised users were larger in samples of Hungary and Ireland, while the Portuguese sample consisted mainly of night life users and German and Dutch respondents mainly of online community users. Poland was the only country with a more even distribution of user groups. However, regardless of sample composition, several clear differences in NPS use were evident. In terms of profile, demographic trends are similar to previous monitoring of NPS (Europol-EMCDDA 2010; Carhart-Harris et al. 2011; Measham et al. 2011b; Werse and Morgenstern 2012; Eurobarometer 2014; Johnston et al. 2015; Martinotti et al. 2015; Global Drug Survey 2016). Recent NPS users in all countries are predominantly male (less than one third female).

In general, recent users of all categories of NPS are mainly young adults aged 18-24 years. The online community sample was the youngest with the majority falling within the 18-24 age group. We know that the internet and social media fuels the marketing, popularity and sale of NPS (Orsolini et al. 2016; Lavorgna 2016) with younger drug users active on online websites (Móró and Rácz 2013; Rosino and Linders 2015; Soussan and Kjellgren 2014, 2016; Van Hout 2014a, b; Van Buskirk et al. 2016; Hearne and Van Hout 2016; Bilgrei 2016; Tzanetakis et al. 2016; Van Hout and Hearne 2015, 2017). Night life users were somewhat older: between 18 and 35 years (average 25.7 years). Most night life users reside in large towns, but online community users often live in small and medium-sized towns. Levels of education are high among both night life and online community users. Marginalised users of NPS were older than the other two samples (average 33.5 years), and predominantly found in large towns, have had little education and were often unemployed.

Use of 'herbal blends' and 'synthetic cannabinoids obtained pure' was most prevalent in Germany, Poland and Hungary, and least prevalent in the Netherlands. In contrast, use of 'branded stimulants' and 'stimulants/empathogens/nootropics obtained pure' was most prevalent in the Netherlands, and least popular in Portugal. Diffusion of both categories has been reported elsewhere (Arfken et al. 2014). The Portuguese and German samples are distinguished by high levels of 'psychedelic' NPS use, and 'dissociative' and 'other' NPS were highest in Germany and lowest in Ireland. In terms of most popular NPS used in these countries, all three categories of NPS users reported majority use of stimulants. This reflects trend data which reports on high demand for synthetic stimulants in Europe due to displacement from traditional drugs such as amphetamine, MDMA and cocaine. With regard to the number of different substances detected in previous years, synthetic cathinones are the second largest group of NPS (EMCDDA 2015). Similar trends are described on contemporary drug fora on the Surface Web (Van Hout 2014b; Van Hout and Hearne 2015; Sande 2016; Hearne and Van Hout 2016).

Similar to Hearne and Van Hout (2016), marginalised NPS users also differed from night life and online community users in terms of reporting a higher prevalence of use of herbal blends and/or synthetic cannabinoids and stimulants, a lower prevalence of psychedelic NPS use, and had less awareness of the active synthetic ingredients in herbal blends. Online community users distinguish from both marginalised and night life users by relatively high levels of benzodiazepine class NPS. This has also been observed in online NPS users active on 
the Darknet (Van Hout and Hearne 2017) and as popular trend in online pharmacies (Littlejohn et al. 2005). There was no difference between NPS user categories in terms of dissociative NPS. Route of administration differed between groups, with marginalised users using commonly via injection, a mode that was used by barely anyone from the other groups. A history of intravenous drug use was relatively prevalent among users of 'herbal blends', 'synthetic cannabinoids obtained pure' and 'dissociatives' NPS.

Dissociatives and synthetic cannabinoids are the substances that are mostly associated to health and social problems. It is important to note that poly use of NPS compounds (sequential and concurrent) and NPS with conventional illicit drugs is common and can exacerbate such acute effects (Van Hout and Hearne 2017). That said, the reported acute side effects support those described in the literature (Stepens et al. 2008; Auwärter et al. 2009; Every-Palmer 2010; Hadlock et al. 2011; Maan and D'Souza 2011; Dargan et al. 2010, Vearrier and Osterhoudt 2010; Lusthof et al. 2011; Kasick et al. 2012; Grandy 2012; Seely et al. 2012; Gunderson et al. 2012; Tung et al. 2012; Werse and Morgenstern 2012; King and Nutt 2014; Soussan and Kjellgren 2015, 2016; Van Hout 2014b; Abdulrahim et al. 2015; Van Hout 2016; Bassir et al. 2016; Van Hout and Hearne 2016, 2017) and include experiences of increased heart rate/palpitation, dizziness, anxiety/horror trips and headaches as the most common symptoms across all three categories. Life time use of herbal blends and/or pure synthetic cannabinoids, branded and/or pure stimulants, and dissociative NPS, but not psychedelic or other NPS is associated with such unpleasant side effects. Online community NPS users, but not night life users, reported less often experiences of acute unpleasant side effects from NPS use than marginalised users. Generally, the relatively high rates of acute side effects experienced by users with experiences in synthetic cannabis use are in line with prior observations that users of such substances report more, and quite divergent, negative side effects than users of other NPS (Werse and Egger 2016), as well as toxicological research that assesses such substances as much more risky than cannabis with regard to overdose and other physical symptoms (Moosmann and Auwärter 2016). Further comparative research is needed to assess whether symptoms experienced by users of particular NPS categories differ from the symptoms experienced after the use of common illicit drugs of the same class of substances.

Marginalised users not only reported substantially more acute and unpleasant side effects than other respondents, but reported particularly much more mid- and long-term mental and physical problems (addiction withdrawals and craving, weight loss, depression and paranoid disorders) and social problems (conflict with partner or family, problems with housing and legal problems) as a consequence of NPS use. These results could be expected, given the risk behaviours associated with injecting and dependent drug use, as well as the precarious social situation of drug users who are marginalised by definition. Mid- and long-term problems are associated with being a marginalised user, living in Ireland, Hungary or Poland, and life time use of herbal blends and/or pure synthetic cannabinoids, branded and/or pure stimulants, and dissociative NPS. Addiction withdrawals and craving were reported by almost half of marginalised users along with weight loss, depression and paranoid disorders. Currently, there is a limited demand for specialist NPS treatment in Europe, despite some Member States identifying a need for such clinical and treatment services (EMCDDA 2016). Social problems are associated with being a marginalised user, living in Ireland or Hungary, and life time use of herbal blends and/or pure synthetic cannabinoids, branded and/or pure stimulants, dissociative NPS, and other NPS. Low proportions of online and nightlife users reported social or legal problems in terms of conflict at school or university, with partners or family, or with housing. 


\section{Conclusion}

The study is illustrative of the need for continued surveillance and monitoring of NPS trends across Europe. The development of country-specific information resources, awareness raising and prevention initiatives particularly around the contents of popular NPS is warranted. Appropriate clinical responses to acute side effects and mid- to long-term problems associated with NPS use across the three NPS user groups are needed, along with enhanced social service supports for NPS user groups experiencing associated problems. Country-specific initiatives in response to user trends should include the regular training of health and social care professionals, health and social service needs assessments, and targeted service responses to reduce incurred harms.

Funding Information The NPS Transnational project received funding under NPS-HOME/2014/JDRU/ AG/DRUG/7077.

\section{Compliance with Ethical Standards}

Conflict of Interest The authors declare that they have no conflict of interest.

Open Access This article is distributed under the terms of the Creative Commons Attribution 4.0 International License (http://creativecommons.org/licenses/by/4.0/), which permits unrestricted use, distribution, and reproduction in any medium, provided you give appropriate credit to the original author(s) and the source, provide a link to the Creative Commons license, and indicate if changes were made.

\section{References}

Abdulrahim, D., Bowden-Jones, O., \& on behalf of the NEPTUNE Expert Group. (2015). Guidance on the management of acute and chronic harms of club drugs and novel psychoactive substances. London: Novel Psychoactive Treatment UK Network (NEPTUNE).

Arfken, C. L., Owens, D., Madeja, C., \& DeAngelis, C. (2014). Exploratory comparative study on the diffusion of synthetic cannabinoids and synthetic cathinones. Journal of Psychoactive Drugs, 465, 362-368.

Auwärter, V., Dresen, S., Weinmann, W., Müller, M., Pütz, M., \& Ferreirós, N. (2009). 'Spice' and other herbal blends: harmless incense or cannabinoid designer drugs? Journal of Mass Spectrometry, 44, 832-837.

Bassir, N. A., Medrano, B., Perkel, C., Galynker, I., \& Hurd, Y. L. (2016). Psychiatric comorbidity associated with synthetic cannabinoid use compared to cannabis. Journal of Psychopharmacology, 3012, 1321-1330.

Bilgrei, O. R. (2016). From "herbal highs" to the "heroin of cannabis": exploring the evolving discourse on synthetic cannabinoid use in a Norwegian Internet drug forum. International Journal of Drug Policy, 29, 18.

Bourne, A., Reid, D., Hickson, F., Torres Rueda, S., \& Weatherburn, P. (2014). The Chemsex study: drug use in sexual settings among gay and bisexual men in Lambeth, Southwark and Lewisham. London: London School of Hygiene and Tropical Medicine, Sigma Research Retrieved from: http://www.sigmaresearch.org. uk/chemsex.

Brauser, D. (2012). Injection of 'bath salts' linked to necrotizing fasciitis. Orthopedics, 35, 124-127.

Brents, L. K., \& Prather, P. L. (2014). The K2/spice phenomenon: emergence, identification, legislation and metabolic characterization of synthetic cannabinoids in herbal incense products. Drug Metabolism Reviews, 46, 72-85.

Carhart-Harris, R. L., King, L. A., \& Nutt, D. (2011). A web-based survey on mephedrone. Drug and Alcohol Dependence, 118(1), 19-22.

Caudevilla, F. (2016). The emergence of deep web marketplaces: a health perspective. The internet and drug markets. (European Monitoring Centre for Drugs and Drug Addiction: Insights 21) (pp. 69-75). Luxembourg: Publications Office of the European Union. 
Caudevilla, F., Ventura, M., Indave Ruiz, B. I., \& Fornís, I. (2013). Presence and composition of cathinone derivatives in drug taken from a drug test service in Spain (2010-2012). Human Psychopharmacology: Clinical and Experimental, 28(4), 341-344.

Colfax, G., Santos, G. M., Chu, P., Vittinghoff, E., Pluddeman, A., Kumar, S., \& Hart, C. (2010). Amphetaminegroup substances and HIV. Lancet, 376, 458-474.

Corazza, O., Assi, S., Simonato, P., Corkery, J., Bersani, F.S., Demetrovics, Z., ... Schifano, F. (2013). Promoting innovation and excellence to face the rapid diffusion of novel psychoactive substances in the EU: the outcomes of the ReDNet project. Human Psychopharmacology: Clinical and Experimental, 284, 317-323.

Csák, R., Demetrovics, Z., \& Rácz, J. (2013). Transition to injecting 3,4-methylene-dioxy-pyrovalerone (MDPV) among needle exchange program participants in Hungary. Journal of Psychopharmacology, 27(6), 559-563.

Dargan, P. I., Albert, S., \& Wood, D. M. (2010). Mephedrone use and associated adverse effects in school and college/university students before the UK legislation change. QJM, An International Journal of Medicine, $103,875-879$.

EMCDDA. (2015). New psychoactive substances in Europe. An update from the EU Early Warning System, 2015. Luxembourg: Publications Office of the European Union Retrieved from: http://www.emcdda.europa. eu/system/files/publications/65/TD0415135ENN.pdf.

EMCDDA. (2016). Health responses to new psychoactive substances. Luxembourg: Publications Office of the European Union Retrieved from: http:/www.emcdda.europa.eu/system/files/publications/2812/TD0216555 ENN.pdf.

Eurobarometer 401 (2014). Young people and drugs. Retrieved from: http://ec.europa.eu/public opinion/flash/fl_401_en.pdf

European Union. (2005). Council of the European Union decision 2005/387/JHA on the information exchange, risk-assessment and control of new psychoactive substances. Official Journal of the European Union, 19(7), $170-175$.

Europol-European Monitoring Centre for Drugs and Drug Addiction (EMCDDA). (2010). Joint report on a new psychoactive substance: 4-methylmethcathinone (mephedrone). Lisbon: EMCDDA-Europol.

Europol-European Monitoring Centre for Drugs and Drug Addiction (EMCDDA). (2016). Annual report on the implementation of council decision 2005/387/JHA. Lisbon: EMCDDA-Europol.

Every-Palmer, S. (2010). Warning: legal synthetic cannabinoid-receptor agonists such as JWH-018 may precipitate psychosis in vulnerable individuals. Addiction, 105, 1859-1860.

Global Drug Survey (2016). Global drug survey. London: Global Drug Survey Ltd.

Grandy, J. K. (2012). Case report: drug toxicity following trip to the local head shop. The Journal of Urgent Care Medicine, 6(9), 22-25.

Gunderson, E. W., Haughey, H. M., Ait-Daoud, N., Joshi, A. S., \& Hart, C. L. (2012). "Spice” and "K2" herbal highs: a case series and systematic review of the clinical effects and biopsychosocial implications of synthetic cannabinoid use in humans. The American Journal on Addictions, 21, 320-326.

Hadlock, G.C., Webb, K.M., McFadden, L.M., Wen Chu, P., Ellis, J.D., Allen, S.C., ... Fleckenstein, A.E. (2011). 4-Methylmethcathinone (mephedrone): neuropharmacological effects of a designer stimulant of abuse. Journal of Pharmacology and Experimental Therapeutics, 339(2), 530-536.

Hearne, E., \& Van Hout, M. C. (2016). "Trip-sitting" in the black hole: a netnographic study of dissociation and indigenous harm reduction. Journal of Psychoactive Drugs, 48(4), 233-242.

Hearne, E., Grund, J. P. C., Van Hout, M. C., \& McVeigh, J. (2016). A scoping review of home produced heroin and amphetamine type stimulant substitutes: implications for prevention, treatment and policy. Harm Reduction Journal, 13, 14.

Hillebrand, J., Olszewski, D., \& Sedefov, R. (2010). Legal highs on the internet. Substance Use and Misuse, 45, $330-340$.

Johnston, L. D., O’Malley, P. M., Miech, R. A., Bachman, J. G., \& JE, S. (2015). Monitoring the future national survey results on drug use: 1975-2014: overview, key findings on adolescent drug use. Institute for social research. Ann Arbor: The University of Michigan.

Kapitány-Fövény, M., Mervó, B., Kertész, M., Corazza, O., Farkas, J., Kökönyei, G., ... Demetrovics, Z. (2015). Is there any difference in patterns of use and psychiatric symptom status between injectors and non-injectors of mephedrone? Human Psychopharmacology, 30, 233-243.

Kasick, D. P., McKnight, C. A., \& Klisovic, E. (2012). 'Bath salt': ingestion leading to severe intoxication delirium: two cases and a brief review of the emergence of mephedrone use. The American Journal of Drug and Alcohol Abuse, 38(2), 176-180.

Kassai, S., Pintér, J., Rácz, J., Böröndi, B., Tóth-Karikó, T., Kerekes, K., \& Gyarmathy, A. (2017). Assessing the experience of using synthetic cannabinoids by means of interpretative phenomenological analysis. Harm Reduction Journal, 14, 9.

King, L. A., \& Nutt, D. J. (2014). Independent scientific committee on drugs. Deaths from 'legal highs': a problem of definitions. Lancet, 383(9921), 952. 
Lavorgna, A. (2014). The online trade in counterfeit pharmaceuticals: new criminal opportunities, trends and challenges. European Journal of Criminology, 12(2), 1-16.

Lavorgna, A. (2016). How the use of the internet is affecting drug trafficking practices. The internet and drug markets. (European Monitoring Centre for Drugs and Drug Addiction: Insights 21) (pp. 90-98). Luxembourg: Publications Office of the European Union.

Littlejohn, C., Baldacchino, A., Schifano, F., \& Deluca, P. (2005). Internet pharmacies and online prescription drug sales: a cross-sectional study. Drugs Education, Prevention and Policy, 12, 75-80.

Lusthof, K. J., Oosting, R., Maes, A., Verschraagen, M., Dijkhuizen, A., \& Sprong, A. G. (2011). A case of extreme agitation and death after the use of mephedrone in The Netherlands. Forensic Science International, 206, e93-e95.

Maan, Z. N., \& D’Souza, A. R. (2011). Spontaneous subcutaneous emphysema associated with mephedrone usage. Annals of the Royal College of Surgeons of England, 94(1), 38-40.

Martinotti, G., Lupi, M., Carlucci, L., Cinosi, E., Santacroce, R., Acciavatti, T., ... Di Giannantonio, M. (2015). Novel psychoactive substances: use and knowledge among adolescents and young adults in urban and rural areas. Human Psychopharmacology, 30, 295-301.

McElrath, K., \& O’Neill, C. (2011). Experiences with mephedrone pre- and postlegislative controls: perceptions of safety and sources of supply. International Journal of Drug Policy, 22(2), 120-127.

Measham, F., Wood, D. M., Dargan, P. I., \& Moore, K. (2011a). The rise in legal highs: prevalence and patterns in the use of illegal drugs and first- and second-generation "legal highs" in South London gay dance clubs. Journal of Substance Use, 16, 263-272.

Measham, F., Moor, K., \& Østergaard, J. (2011b). Emerging drug trends in Lancashire: night time economy surveys phase one report. LDAAT emerging drug trends-phase 1 report April 2011. Lancaster: Lancashire Drug and Alcohol Action Team, Dept of Applied Social Science.

Moosmann, B., \& Auwärter, V. (2016). Pharmakologie und Toxikologie synthetischer CannabinoidrezeptorAgonisten. In M. von Heyden, H. Jungaberle, \& T. Majic (Eds.), Handbuch psychoaktive Substanzen. Berlin: Springer Berlin Heidelberg.

Móró, L., \& Rácz, J. (2013). Online drug user-led harm reduction in hungary: a review of Daath. Harm Reduction Journal, 10, 18.

Orsolini, L., Francesconi, G., Papanti, D., Giorgetti, A., \& Schifano, F. (2016). Profiling online recreational/ prescription drugs' customers and overview of drug vending virtual marketplaces. Human Psychopharmacology, 30(4), 302-318.

Papaseit, E., Farré, M., Schifano, F., \& Torrens, M. (2014). Emerging drugs in Europe. Current Opinion in Psychiatry, 27, 243-250.

Pas, M. (2010). Mephedrone in Slovenia. Ljubljana: DrogArt report.

Psychonaut Web Mapping Research Group. (2009). Mephedrone report. London: Institute of Psychiatry, King's College.

Rácz, J., Csák, R., Tóth, K. T., Tóth, E., Rozmán, K., \& Gyarmathy, V. A. (2016). Veni, vidi, vici: the appearance and dominance of new psychoactive substances among new participants at the largest needle exchange program in Hungary between 2006 and 2014. Drug and Alcohol Dependence, 158, 154-158.

Reuter, P., \& Pardo, B. (2017). Can new psychoactive substances be regulated effectively? An assessment of the British psychoactive substances bill. Addiction, 112, 25-31.

Rosino, M., \& Linders, A. (2015). Howard Becker in hyperspace: social learning in an on-line drug community. Deviant Behavior, 36(9), 725-739.

Sande, M. (2016). Characteristics of the use of 3-MMC and other new psychoactive drugs in Slovenia, and the perceived problems experienced by users. International Journal of Drug Policy, 27, 65-73.

Schmidt, M. M., Sharma, A., Schifano, F., \& Feinmann, C. (2010). "Legal highs" on the net-evaluation of UKbased websites, products and product information. Forensic Science International, 206(1-3), 92-97.

Schmidt, A. J., Bourne, A., Weatherburn, P., Reid, D., Marcus, U., Hickson, F., \& EMIS Network. (2016). The EMIS Network Illicit drug use among gay and bisexual men in 44 cities: findings from the European MSM Internet Survey (EMIS). International Journal of Drug Policy, 38, 4-12.

Seely, K. A., Lapoint, J., Moran, J. H., \& Frattore, L. (2012). Spice drugs are more than harmless herbal blends: a review of the pharmacology and toxicology of synthetic cannabinoids. Progress in NeuroPsychopharmacology \& Biological Psychiatry, 39, 234-243.

Soussan, C., \& Kjellgren, A. (2014). The flip side of "spice": the adverse effects of synthetic cannabinoids as discussed on a Swedish internet forum. Nordic Studies on Alcohol and Drugs, 31, 207-220.

Soussan, C., \& Kjellgren, A. (2015). "Chasing the high"- experiences of ethyl-phenidate as described on international internet forums. Substance Abuse: Research and Treatment, 9, 9-16.

Soussan, C., \& Kjellgren, A. (2016). The users of novel psychoactive substances: online survey about their characteristics, attitudes and motivations. International Journal of Drug Policy, 32, 77-84. 
Spaderna, M., Addy, P. H., \& D’Souza, D. C. (2013). Spicing things up: synthetic cannabinoids. Psychopharmacology, 228, 525-540.

Stepens, A., Logina, I., Liguts, V., Aldins, P., Eksteina, I., Platkajis, A., ... Donaghy, M. (2008). A Parkinsonian syndrome in methcathinone users and the role of manganese. New England Journal of Medicine, 358(10), 1009-1017.

Tung, C. K., Chiang, T. P., \& Lam, M. (2012). Acute mental disturbance caused by synthetic cannabinoid: a potential emerging substance of abuse in Hong Kong. East Asian Archives in Psychiatry, 22, 31-33.

Tzanetakis, M., Kamphausen, G., Werse, B., \& von Laufenberg, R. (2016). The transparency paradox. Building trust, resolving disputes and optimising logistics on conventional and online drugs markets. International Journal of Drug Policy, 35, 58-68.

UNODC. (2013). World drug report. Vienna: United Nations.

van Amsterdam, J. G., Nabben, T., Keiman, D., Haanschoten, G., \& Korf, D. (2015). Exploring the attractiveness of new psychoactive substances (NPS) among experienced drug users. Journal of Psychoactive Drugs, 47(3), 177-181.

Van Buskirk, J., Roxburgh, A., Bruno, R., Naicker, S., Lenton, S., Sutherland, R., ... Burns, L. (2016). Characterising dark net marketplace purchasers in a sample of regular psychostimulant users. International Journal of Drug Policy, 35, 32-37.

Van Hout, M. C. (2014a). Kitchen chemistry: a scoping review of the diversionary use of pharmaceuticals for non-medicinal use and home production of drug solutions. Drug Testing and Analysis, 6(7-8), 778-787.

Van Hout, M. C. (2014b). An Internet study of user's experiences of the synthetic cathinone, 4methylethcathinone (4-MEC). Journal of Psychoactive Drugs, 46(4), 273-286.

Van Hout, M.C. (2016). The dynamic landscape of novel psychoactive substance use in Ireland: results from an expert consultation. International Journal of Addiction and Mental Health. Early Online.

Van Hout, M. C., \& Bingham, T. (2012). A costly turn on: patterns of use and perceived consequences of mephedrone based head shop products amongst Irish injectors. International Journal of Drug Policy, 23(3), 188-197.

Van Hout, M. C., \& Bingham, T. (2013a). Silk road, the virtual drug marketplace: a single case study of user experiences. International Journal of Drug Policy, 24(5), 385-391.

Van Hout, M. C., \& Bingham, T. (2013b). Surfing the silk road: a study of users' experiences. International Journal of Drug Policy, 24(6), 524-529.

Van Hout, M. C., \& Hearne, E. (2015). 'Word of mouse': indigenous harm reduction and online consumerism of the synthetic compound methoxphenidine. Journal of Psychoactive Drugs, 47(1), 30-41.

Van Hout, M. C., \& Hearne, E. (2016). User experiences of development of dependence on the synthetic cannabinoids, 5f-AKB48 and 5F-PB-22, and subsequent withdrawal syndromes. International Journal of Addiction and Mental Health, 15(3), 565-579.

Van Hout, M. C., \& Hearne, E. (2017). New psychoactive substances (NPS) on cryptomarket fora: an exploratory study of characteristics of forum activity between NPS buyers and vendors. International Journal of Drug Policy, 40, 102-110.

Vearrier, D., \& Osterhoudt, K. C. (2010). A teenager with agitation: higher than she should have climbed. Pediatric Emergency Care, 26, 462-465.

Werse, B., \& Egger, D. (2016). Neue psychoaktive Substanzen: Konsummuster, Konsummotive, Nebenwirkungen und problematischer Konsum. In M. von Heyden, H. Jungaberle, \& T. Majic (Eds.), Handbuch psychoaktive Substanzen. Berlin: Springer.

Werse, B., \& Morgenstern, C. (2012). How to handle legal highs? Findings from a German online survey and considerations on drug policy issues. Drug and Alcohol Today, 12, 222-231.

Wood, D., Measham, F., \& Dargan, P. (2012). 'Our favourite drug': prevalence of use and preference for mephedrone in the London night-time economy 1 year after control. Journal of Substance Use, 17, 91-97. 